\title{
China’s Electricity Industry at the Crossroads: New Challenges for Developing the Right Model of Regulation
}

\author{
Anastassios Gentzoglanis \\ University of Sherbrooke, Sherbrooke, Canada
}

\begin{abstract}
China is facing important challenges stemming from increasing rates of urbanization and aging population. To pursue its "harmonious society" objective without disrupting its path to development major overhauls are necessary in education, health, social security and above all in public services, particularly in electricity. China's electricity industry is at the crossroads. To meet the challenges, new models of regulation should be developed and applied. This paper examines the current state of the Chinese electricity industry and the burden it imposes on its public finances. It also reviews and critically examines the existing FIT (Europe) and RPS (USA) models of regulation and of promotion of renewable energies and advances on whether they are advantageous for China. It is argued that the electricity industry has already undergone important reforms but cross subsidies still exist, equivalent to $1.5 \%$ of China's GDP. Drastic rate rebalancing policies will create sustainability problems and a deterioration of China's public finances. To avoid such negative results, China has to further reform its electricity industry gradually and use wisely FIT-type programs to bring renewables into the grid and fulfill the Kyoto Protocol.
\end{abstract}

Keywords: alternative models of regulation, China's public finances, cross subsidies, FIT and RPS programs, regulation of electricity industry, renewable energy

\section{Introduction}

The rapid growth rates in urbanization have created a number of problems for the Chinese government, among them the most significant are considered to be the creation of an adequate infrastructure and the provision of a rather good quality of services. But infrastructure development requires huge investments and public financing is getting increasingly strenuous and expensive. State-owned enterprises (SOEs) have "non-optimal" capital structures and depend heavily on public sources to fund their expansion plans. As an example, China's electric network companies have a (non-optimal) debt ratio ranging from $70 \%$ to $80 \%$, which is much higher than the $45 \%-55 \%$ of major industrialized and emerging economies. The increasing growth in demand for urban public goods and services makes their public provision questionable, particularly in the long run. For instance,

Anastassios Gentzoglanis, Full Professor, Ph.D., Center for the Study of Regulatory Economics and Finance, University of Sherbrooke, CIRST and GReFA.

Correspondence concerning this article should be addressed to Anastassios Gentzoglanis, 2500, University Bould, Sherbrooke, Quebec J1K-2R1, Canada. E-mail: anastassios.gentzoglanis@USherbrooke.ca. 
adequacy and reliability are two major issues in the provision of electricity in major urban and rural areas in China. According to Chinese government, investment in electricity infrastructure has to increase fast and the use of new sources of energy such as the construction of wind farms, solar parks and other renewables must be given priority (Dow Jones International News, 2010). To meet these challenges, the Chinese government is in search of new models which would allow it to provide an acceptable level of public goods and services to its urban population, safeguard an adequate level of non-inflationary economic growth and respect the environment while keeping its public finances afloat. The current reforms undertaken in the electricity sector, illustrate well the preoccupation of the Chinese government to address the problems of urbanization and long term economic growth (Xu \& Chen, 2006).

International experiences and best practices provide an interesting and informative avenue to explore before any definite policies are adopted by China to address these issues at home. For instance, with respect to the Kyoto protocol, governments have to adopt policies which affect both the public finances, the cost of provision of public services and firms' financial performance. The electricity industry is a major contributor to $\mathrm{CO}_{2}$ and the policies adopted by a country to contain them are not without costs. The latter may be large or low depending on the model. Till now, to promote investment in infrastructure and reduce gas emissions, governments (LBNL, 2008; NREL, 2010; NARUC, 2010; CPUC, 2009) have had implemented either the FIT (feed-in tariff model, mostly in Europe) or the RPS model (renewable portfolio standard, mostly in the US). The first one has been the most successful but also the most expensive. The latter have had a rather limited success but it is far cheaper to implement. Given the high costs and the impact the implementation of environmental programs can have on public finances, governments are increasingly question their ability to provide safely and reliably these goods to their citizens. In the area of electricity and the environment, the governments around the world have restructured their industries and provided incentives to the private sector so as to develop the necessary infrastructure.

Since the early reforms of its electricity sector in the 1980s, China has not succeeded to reduce the financial dependence of its electricity industry from central government. For instance, for the period 1996-2000, the reforms to access private finance and investment in electricity infrastructure have generated a meager \$ 12.2 billion. The rest, \$ 58.2 billion, was mostly financed by the central (44.6\%) and local government sources (19.4\%). China's electricity reforms can be classified in various phases; the old system (pre-1985) period; 1st phase, 1986-1996; 2nd phase, 1997-2001; and 3rd phase, 2002-2010 (SEC, 2010). Despite the three reform phases, the central government is still the main actor in ownership, control, operation and regulatory functions. ${ }^{1}$ China's problems of shortage of power supply and the lack of electricity infrastructure lie mostly in its inability to find sources to adequately finance these huge investments. More market reforms and new regulatory mechanisms should be envisaged to attract international financing and reduce the stringencies these investments impose on its public finances. The problems of public provision of the electricity, created by increased demand for energy in major urban areas, may be attenuated by accelerating the reforms already undertaken. International experiences may guide China in finding the best regulatory mechanism that would be more efficient and less demanding on public purse.

\footnotetext{
${ }^{1}$ There are some minor improvements on the structure of the electricity industry created by the reforms. For instance, during the 3rd phase the generation segment was disintegrated and during the 1st phase the Chinese government has introduced limited private participation of independent power producers (IPPs).
} 
This paper addresses these questions and explores the possibilities for the adoption of a model which would reduce China's dependency on public financing while it would safeguard the expansion of its electricity infrastructure and the provision of an adequate quantity and quality of this good to its citizens. The paper draws on international experiences with respect to the reforms undertaken in the electricity sector and critically analyzes the various models in use around the world. It also questions the validity of these models for China. This paper contributes to the existing literature by advancing the knowledge of the functioning of the electricity industry in a context of increasing urbanization, stringency in public finances and adequacy in the provision and investment in electricity infrastructure. To the best of the author's knowledge, there are no similar studies on this subject. The literature review at the international level and the review of the scant literature on China's electricity industry provide useful insights to the issues of financing China's electricity infrastructure and the way regulatory reforms may contribute to alleviating China's problems of public provision of electricity. This study sheds light at these issues, contributes to the literature and is useful to academia, industry analysts and policy makers alike.

Section 2 deals with China's fiscal accounts and the issues of urbanization and the provision of public services, particularly electricity. It analyzes the current debate about the role of public sector in the provision of public services and the sustainability of public finances. Section 3 examines the current level of regulation of the electricity industry in China and its regulatory reforms aiming at expanding the electricity services to its growing urban population and ever increasing demand for energy by many export-oriented industrial sectors. The new policies concerning the development of energy based on renewable energy sources (RES) are critically examined and assessed chiefly with respect to their impact on China's public finances. Section 4 presents, in some detail, two regulatory frameworks used elsewhere (in Europe and the USA) to deal with similar issues which China is facing currently. Section 5 concludes and offers policy recommendations.

\section{China's Fiscal Accounts and the Issues of Urbanization-Challenges for the Development of Services in Infrastructure Industries}

The recent financial crisis has changed dramatically the economic and financial international landscape and with that some key financial statistics. For the first time emerging and low income countries are better positioned than industrialized countries in terms of fiscal accounts. The crisis led advanced countries into mounting debt and low prospects for growth weakening thereby their capacity to improve their fiscal accounts in the medium and long runs. Figure 1 shows that since the beginning of the financial crisis emerging and G-20 emerging countries have a debt-to-GDP ratio oscillating around 40\% while the G-20 have a hovering ratio of around $110 \%$.

China's fiscal accounts are in much better shape than other western and developing economies. China's export capacity and its sustained growth, even under the current strenuous worldwide financial crisis, are the driving forces behind this exceptional performance. Table 1 shows China's current and projected (World Bank, 2010) global economic indicators and its vigorous performance. But China's traditional policies, consisting in strong government presence in the markets and particularly in financing SOEs, drain enormous revenues towards these sectors and this exerts increasing pressures on China's future ability to sustain high levels of economic development and social stability. Major demographic changes and high urbanization rates that are expected to surge with China's growing industrialization would bring more changes in fiscal policies particularly in health, education, social protection and public services. 


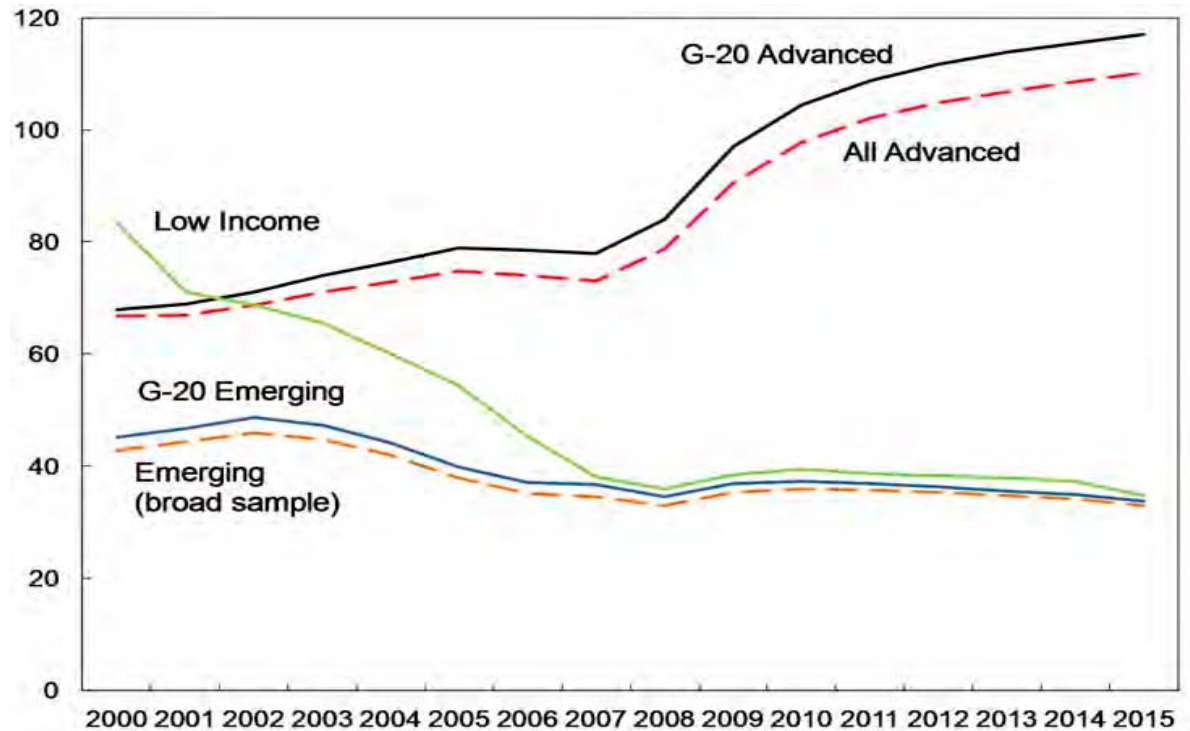

Figure 1. General government debt ratios (percent of GDP, 2009, PPP-GDP weighted average). Source: IMF (2010, p. 12), Fiscal Monitor. Retrieved from http://www.imf.org/external/pubs/ft/fm/2010/fm1001.pdf.

Table 1

China's Main Economic Indicators (in \%, Unless Otherwise Indicated)

\begin{tabular}{|c|c|c|c|c|c|}
\hline Year & 2007 & 2008. & 2009 & 2010 & 2011(est.) \\
\hline The real economy & 13.0 & 9.6 & 8.7 & 9.5 & 8.5 \\
\hline Domestic demand & 10.8 & 9.4 & 13.8 & 9.6 & 8.5 \\
\hline Consumption & 10.2 & 8.8 & 9.7 & 9.5 & 9.1 \\
\hline Gross capital formation & 11.4 & 10.2 & 18.3 & 9.7 & 8.0 \\
\hline \multicolumn{6}{|l|}{ Contribution to GDP growth (PP) } \\
\hline Domestic demand & 10.4 & 8.8 & 12.7 & 9.1 & 8.3 \\
\hline Net exports & 2.6 & 0.8 & -4.0 & 0.4 & 0.3 \\
\hline Contribution net exports (WB, PP) & 3.5 & 1.8 & -4.8 & 0.4 & 0.3 \\
\hline Exports (goods and services) & 20.0 & 8.6 & -10.4 & 23.0 & 8.9 \\
\hline Imports (goods and services) & 14.2 & 5.1 & 4.3 & 26.4 & 9.0 \\
\hline Potential GDP growth & 10.4 & 10.1 & 10.0 & 9.3 & 8.8 \\
\hline Output gap (PP) & 2.4 & 1.9 & 0.5 & 0.7 & 0.5 \\
\hline CPI increases (period average) (\%) & 4.8 & 5.9 & -0.7 & 3.7 & 2.8 \\
\hline GDP deflator & 7.4 & 11.4 & -2.1 & 3.7 & 2.6 \\
\hline External terms of trade & -0.9 & -4.3 & 8.6 & -6.4 & -0.1 \\
\hline \multicolumn{6}{|l|}{ Fiscal accounts (\% of GDP) } \\
\hline Budget balance & 0.6 & -0.4 & -2.8 & -2.8 & -2.5 \\
\hline Revenues & 19.9 & 19.5 & 20.6 & 19.5 & 19.7 \\
\hline Expenditures & 19.3 & 19.9 & 23.4 & 22.2 & 22.2 \\
\hline \multicolumn{6}{|l|}{ External accounts (\% of GDP) } \\
\hline Current account balance (US bln) & 372 & 426 & 297 & 260 & 300 \\
\hline Current account balance (\% GDP) & 11.0 & 9.4 & 6.1 & 4.7 & 4.7 \\
\hline Foreign exchange reserves (US bln) & 1,529 & 1,946 & 2,400 & 2,705 & 3,028 \\
\hline \multicolumn{6}{|l|}{ Other } \\
\hline Broad money growth (M2) & 16.7 & 17.8 & 27.0 & 17.0 & $\mathrm{n} / \mathrm{a}$ \\
\hline
\end{tabular}

http://siteresources.worldbank.org/CHINAEXTN/Resources/318949-1268688634523/Quarterly_June_2 010.pdf. 
Under the ever-increasing pressure of rapid industrialization China has already undertaken or is about to undertake a number of policies that will overhaul its entire fiscal system and its relationship with the local governments. The most stressing areas concern the reforms in:

- Health and education. Increasing spending in these areas is deemed necessary because they constitute China's main pillars of sustained growth. Further, spending in these areas has important positive externalities making the social benefits of these policies higher than their costs. They constitute a means to increase and/or sustain household incomes which further contribute to increasing household consumption. China's dependence on exports makes this country vulnerable to shocks from abroad and boosting domestic demand has become an important goal of the Chinese government. Increased spending in these sectors will contribute to the breaking of China's dependence on exports;

- Pension system. China's social security system needs major overhauls because of drastic changes that are taking place in Chinese demographics and the rapid aging of its working force. To make it more sustainable, the pension system needs capital injections from the government and important modifications in employers'/employees' contributions. To the extent that an important proportion of the work force is still with SOEs an overhaul of the social security system will exert considerable pressures on fiscal accounts ${ }^{2}$;

- SOEs and their pricing policies. It is well known that in many parts of the world SOEs are used as vehicles for economic development. In China prices are used extensively as a means to attain certain social objectives and as a vehicle of economic development. Energy with subsidized prices is a major area of concern. Energy along side with land, water and other natural resources are constantly underpriced in China. These lower than market prices deprive the government of revenues and the subsidized rates increase government expenses. Further, given that subsidized rates lead to overconsumption of subsidized services and considering that the production and consumption of these services (electricity in this case) are increasing pollution, the Chinese government has to spend additional funds to contain pollution and incentivize the use of clean technologies. China's pricing mechanisms do not take into account neither depletion costs nor the negative externalities of production and consumption of polluting public services. The reforms undertaken lately aiming at ending subsidized electricity prices to energy-intensive industries and the tariff "rebalancing" initiatives in the water and fuel industries are at the right direction. The introduction of an ad valorem tax on oil and gas is also welcomed measures which will alleviate some strain on China's public finances ${ }^{3}$.

China's fiscal system reforms concern, far and foremost, its long established financing policies of various infrastructure industries and SOEs. Figure 2 shows the central government's recent surge in lending to major infrastructure projects. Although this is rightfully justified on the grounds of the recent financial crisis, the questions that arise are multiple but two of them are of paramount importance. On the one hand, to what extent the central government would be able to withdraw itself from these projects and on the other hand, what kind of financial commitments are necessary for the long term operations of these infrastructure projects?

\footnotetext{
${ }^{2}$ Other fiscal reforms are welcome in China. For instance, the introduction of a tax on capital gains, of a VAT on services and the distribution of more generous dividends to the government by the SOEs will contribute to the government's revenues.

3 The introduction of a 5\% ad valorem tax on oil and gas was announced in Xinjiang in July 2010 (Retrieved from http://frfry.com/world/china/20100602/resources-tax-reform-was-officially-launched-in-xinjiang-crude-oil-natural-gas-tax-rate-w as-5/).
} 


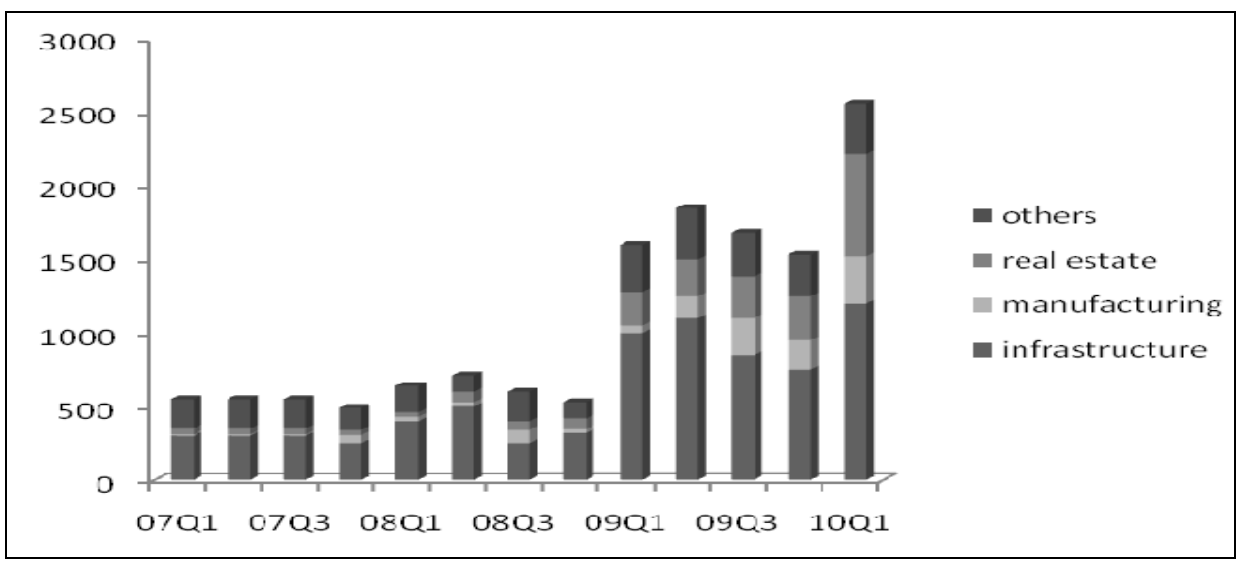

Figure 2. China's lending to infrastructure and other sectors (quarterly increase of medium to long term loans, RMB bn). Source: World Bank (2010, p. 17), Retrieved from http://siteresources.worldbank.org/chinaextn/resources/ 318949-1268688634523/ quarterly_june_2010.pdf.

If the financing of major infrastructure projects may be considered as a temporary or cyclical phenomenon, the subsidization and mispricing of many public services is more permanent and remains a thorny issue for the central government. The latter has still a long way to come to grips with the issues of rate rebalancing in the energy sector in general and in the electricity industry in particular. Any major and rapid rate rebalancing may improve central government's fiscal accounts but it may disrupt its "harmonious society" objective and compromise the path of economic development that has be chosen and followed so successfully by China.

\section{Urbanization, Public Services, Environmental Concerns and China's Fiscal Policies}

Over the past decades, China's reforms have led to greater power for local governments. Local authorities are now the decision-making units in many jurisdictions and exert a control over resources. This devolution of decision-making has created a divergence in the objectives between the central government and local governments. While the central government takes seriously the environmental concerns and the costs that have created the high levels of pollution, local governments are chiefly interested in achieving high levels of development, frequently at the expense of the environment ${ }^{4}$. New institutions, regulations and programs have been created to provide incentives that have as an objective the harmonization of the divergent interests at both levels of governments. For example, in March 2008, the central government made significant reforms in its ministries (the so-called SMR or super-ministry reform (Qiu \& Li, 2009) and pursuant to it the State Environmental Protection Agency (SEPA) got a full ministerial status with explicit mandate to implement and monitor environmental regulations ${ }^{5}$.

Central government's ambitious environmental objectives, as they are articulated in the 5-year economic blueprints, are costly to realize. For instance, according to the current (2005-2010) blueprint, energy intensity, the ratio of energy use per unit of GDP, is targeted to be cut by $20 \%$ and the $\mathrm{SO}_{2}$ emissions by $10 \%$ (by 2010 relative to the 2005 levels). However, the objectives of the Kyoto Protocol cannot be attained without taking more aggressive policies. The central government has thus adopted various other programs to promote the use of renewable sources of energy (RES). These programs while reduce pollution they also increase capacity

\footnotetext{
${ }^{4}$ Local officials are remunerated and promoted based on their capacity to achieve high rates of economic growth.

${ }^{5}$ For details on the reforms, see Qiu and $\mathrm{Li}$ (2009) at http://www.epa.gov/ogc/china/xin.pdf.
} 
availability and alleviate the problems with energy shortages. It has been targeted to increase the use of RES at an accelerating rate in order to provide energy to cover 16\% of the country's needs by the year 2020 (from 7\% now). But the launch of the biomass and wind programs, the implementation of clean development mechanisms (CDM) and the environmental impact assessment policies are costly to implement and they impact negatively on central government public finances. For instance, the biomass program uses an incentive risk-sharing mechanism according to which firms are allowed to earmark funds before paying taxes to the government to hedge risks arising from oil price shocks. Thus when oil prices are very low and losses are rising the earmarked funds could be used to compensate for the losses and sustain the deficit-run operations.

Under the wind power program, the government cut by half the VAT (value-added tax), from $17 \%$ to $8.5 \%$, had lowered the duty rate on domestic investment in wind power from $23 \%$ to $6 \%$, and imported equipment is totally exempted from import duties ${ }^{6}$. Further, the government-run Wind Power Concession Program (WPCP) offers a guaranteed tariff for wind electricity ${ }^{7}$ and administers the auction market for the rights of wind power development. We are not aware of an official study that makes an evaluation of the costs of these programs on government's budget for China but judging from the experience in other countries that have used similar programs, they must be quite pricey. In addition, most of the time there are costs overruns and once these programs are set up it is difficult to phase them out since they create important rents to their owners and a lot of resistance in case of abandonment. For instance, a recent European study (Klein et al., 2008) of FIT (feed-in tariffs) programs shows that the costs of wind and biomass energy in France have increased rapidly during the past few years and this have had a negative impact on French public finances and the purse of consumers (see Figure 3 and Table 2).

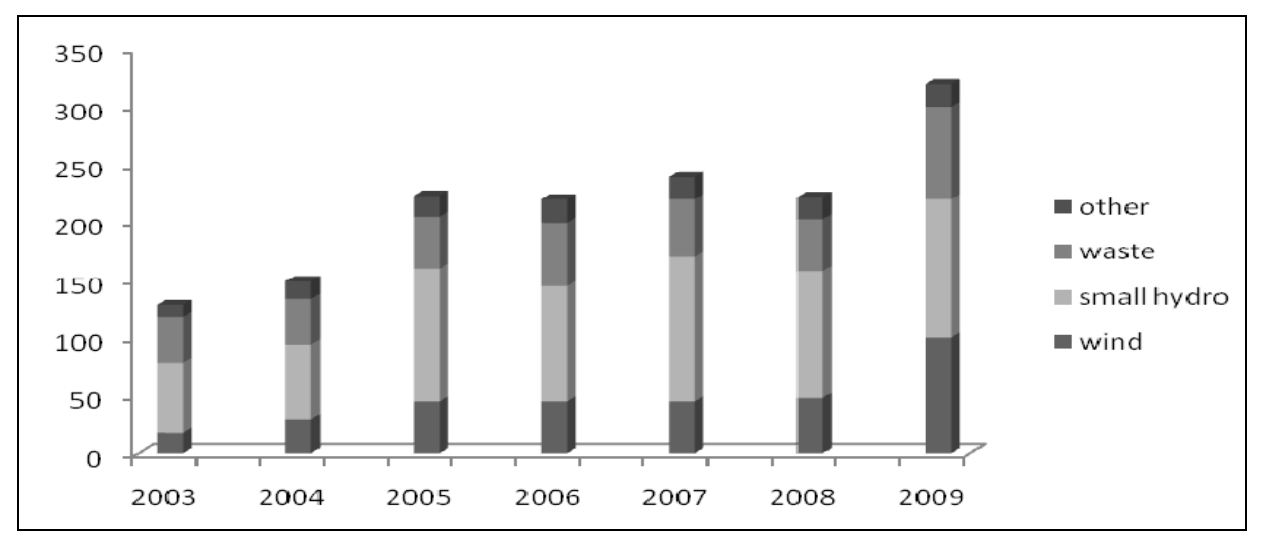

Figure 3. The cost of French renewable energies (TWh in million €). Source: Gipe (2010), http://www.grist.org/article/2010-09-13-feed-in-tariffs-saved-french-ratepayers-money-renewables-energy

The recent financial crisis has modified substantially China's fiscal stance making it difficult to judge the nature and the direction of its fiscal policies in the longer run. The situation became blurred particularly because of the massive economic stimulus plan introduced by the central government in the midst of the world financial crisis. This plan was underfunded and local governments were caught into huge spending obligations without adequate financing. To overcome the underfunding problem, local governments ingeniously have set up investment entities which could borrow money on their behalf. These local government investment platforms

\footnotetext{
${ }^{6}$ Local governments have adopted similar programs. For instance Inner Mongolia applies a 6\% VAT on wind power.

7 This is a kind of feed-in tariff scheme discussed later in the text.
} 
(LGIPs) could use the land given to them by local governments as collateral to get the funds from banks (World Bank, 2010). These funds could then be used to finance local governments' investment projects.

Table 2

Over Cost of French Renewable Energies

\begin{tabular}{|c|c|c|c|c|c|c|c|c|}
\hline \multicolumn{9}{|c|}{ Over cost of French renewable tariffs and generation } \\
\hline & TWh & 2003 & 2004 & 2005 & 2006 & 2007 & 2008 & 2009 \\
\hline Wind & & 0.4 & 0.6 & 0.9 & 1.6 & 3.0 & 5.5 & 7.5 \\
\hline Small hydro & & 3.2 & 4.5 & 7.8 & 6.2 & 6.6 & 6.7 & 6.1 \\
\hline Waste & & 2.0 & 2.4 & 2.1 & 2.3 & 2.6 & 1.8 & 3.5 \\
\hline Other & & 0.6 & 0.6 & 0.5 & 0.7 & 0.5 & 0.4 & 0.4 \\
\hline Total & & 6.2 & 8.1 & 11.3 & 10.7 & 12.6 & 14.5 & 17.4 \\
\hline Over cost & Million $€$ & 141.1 & 198.7 & 89.3 & 110.8 & 322.5 & -5.2 & 93.8 \\
\hline
\end{tabular}

http://www.grist.org/article/2010-09-13-feed-in-tariffs-saved-french-ratepayers-money-renewables-energy.

It is doubtful that the returns on these investments would be able to cover the interest and capital payments and other forms of payment should be envisaged; either an increase in taxes and/or a bailout from the central government. To avoid either eventuality the central government's overarching goal has been the control of lending to LGIPs, although lending to such platforms has been the main characteristic of China's development strategy. According to estimates from the China Banking Regulatory Commission (CBRC) total local government debt was RMB 8 trillion at the end of 2009. LGIP accounted for $92.5 \%$ of the total, i.e., RMB 7.4 trillion $^{8}$. It is true that these figures are astronomical but it is expected that only few local governments would encounter serious problems with this type of lending. Further, it is very unlikely that it can create serious problems, like systemic risk.

Admitting that it is important to constrain LGIPs' lending is one thing but how exactly to do it is completely a different matter. The problem is compounded by the fact that the initial lending has become multifold by the creation of more credit. Recognizing that, in case of bankruptcy, the risks of contagion are high, the State Council (SC, May-June, 2010) has issued directives asking local governments for a tighter regulation and a better management of LGIPs and their lending activities as an effective means to control fiscal and financial risks. It also required a stop in lending to financing vehicles which depend on fiscal revenues to service their debt. The SC went even a step further asking banks to use stricter rules when they lend to LGIPs. The SC called on local governments to abide with the existing rules and regulations which prohibit them from offering loans guarantees. This was a policy consistent with the one adopted by the CBRC earlier as an effort to regulate and monitor LGIP loans. To what extent these directives will be really effective and whether local governments would abide with these regulations is quite uncertain, particularly when local officials are remunerated on spending and not on saving.

It is important to underline that what matters here is China's public debt sustainability, measured as the ratio of debt to GDP. It is true that this ratio to be sustainable must have a limit and cannot grow indefinitely. If GDP grows at increasing rates, as long as the growth rate of a country's debt is lower that its GDP growth, the country can experience high fiscal deficits for a long time, and markets’ perceptions remain still positive. By the same

${ }^{8}$ These statistics are disputed and according to some other estimates (Kuijs, 2010) LGIPs owe around CNY 11 trillion or about 1/3 China's GDP. 
token, markets perceive a high debt level as sustainable if it is declining. Financial markets react negatively when a country's public debt is growing rapidly and simultaneously the level of debt to GDP ratio is considered as high. In short, public debt is sustainable when it is consistent with a stable equilibrium path of the economy. When the underlying economic policies are stable and the economy's growth rates are constant and quite respectable, a country's public debt may be viewed by financial markets as sustainable. But fiscal policies may change drastically as it was the case with the current financial crisis or because there are supply shocks arising from sudden increase in the prices of raw materials or because of a change in policy due to social unrest or international pressures. All these factors are present in the Chinese economy implying that developments expected to be sustainable ex ante may turn unsustainable ex post.

For instance, the high growth rates of the Chinese economy require huge and constant supplies of raw materials particularly coal for the production of energy. If coal supplies are not guaranteed and the price of coal goes up drastically and/or energy is produced by alternative sources which are more expensive, then these adverse events may turn the Chinese economic development unsustainable. This will have negative repercussions on China's ability to sustain high levels of public debt and budget deficits. Mounting international pressures make China more responsive to international sensitivities and this provides incentives to reduce pollution to acceptable levels. Should China concede and implement its pollution-fighting policies drastically, this would have a negative impact on the perceptions and the way markets view China's finances. If the new conditions are viewed as unsustainable by the financial markets then China has to pay fatty premiums to get financing.

By the same token, a rate rebalancing of essential public services may create unsustainable conditions which would impact negatively on China's growth prospects. As global financial markets become more risk averse, China's public debt may not be accepted without hefty premiums. China, with its efforts to satisfy the increasing needs of its urban and rural populations, has to revamp the pricing mechanisms and the supply of public services. To keep its sustainable path of development without disrupting significantly its public finances, China has to proceed gradually and consistently. This is what happened with China's overhaul of its electricity industry. The next sections analyze the current restructuring policies undertaken by China during the past decades to modernize its electricity industry and to introduce market mechanisms for price determination and investment in infrastructure.

\section{Structure of China's Electricity Sector and Main Regulatory Reforms-In Search of an Optimal Model}

\section{Structure of China's Electricity Sector}

China has one of the largest electricity systems in the world. By the end of 2010, its total power installed capacity reached 950 million kilowatts. China's electricity generation is dominated by the production of thermal power, 700 million kilowatts or $73.68 \%$ of its total capacity (China Electricity Council statistics, 2010). Increasingly, China is favoring the production of energy from other sources including renewables reducing thereby the production of thermal power in its portfolio of total national energy production. Official Chinese statistics (end of 2009) confirm the construction of 178 million kilowatts of electricity generation capacity, thermal accounting for 80 million kilowatts and 96.2 of hydropower, nuclear and wind power.

The year 2009 was also one of major changes in China's energy policy because this year the nuclear power generation has increased considerably (nuclear and hydropower generation capacity surpassed the thermal power 
by 10 million kilowatts, in 2009) ${ }^{9}$. By the end of 2010, hydropower, nuclear power and wind power installed capacity would account for $26 \%$ of the national total, reversing the trend of increasing thermal capacity since the 1980s. The past four years China's electricity industry has been transformed by the closure of small thermal power plants. The Ministry of Industry and Information (2009) reported that 26.17 million kilowatts have been lost from the shutdown of small thermal power plants in 2009 and the encouragement of clean energy. In 2009, China invested 371.13 billion Yuan in electricity construction, particularly in renewables with an effort to reduce its investments in thermal power industry.

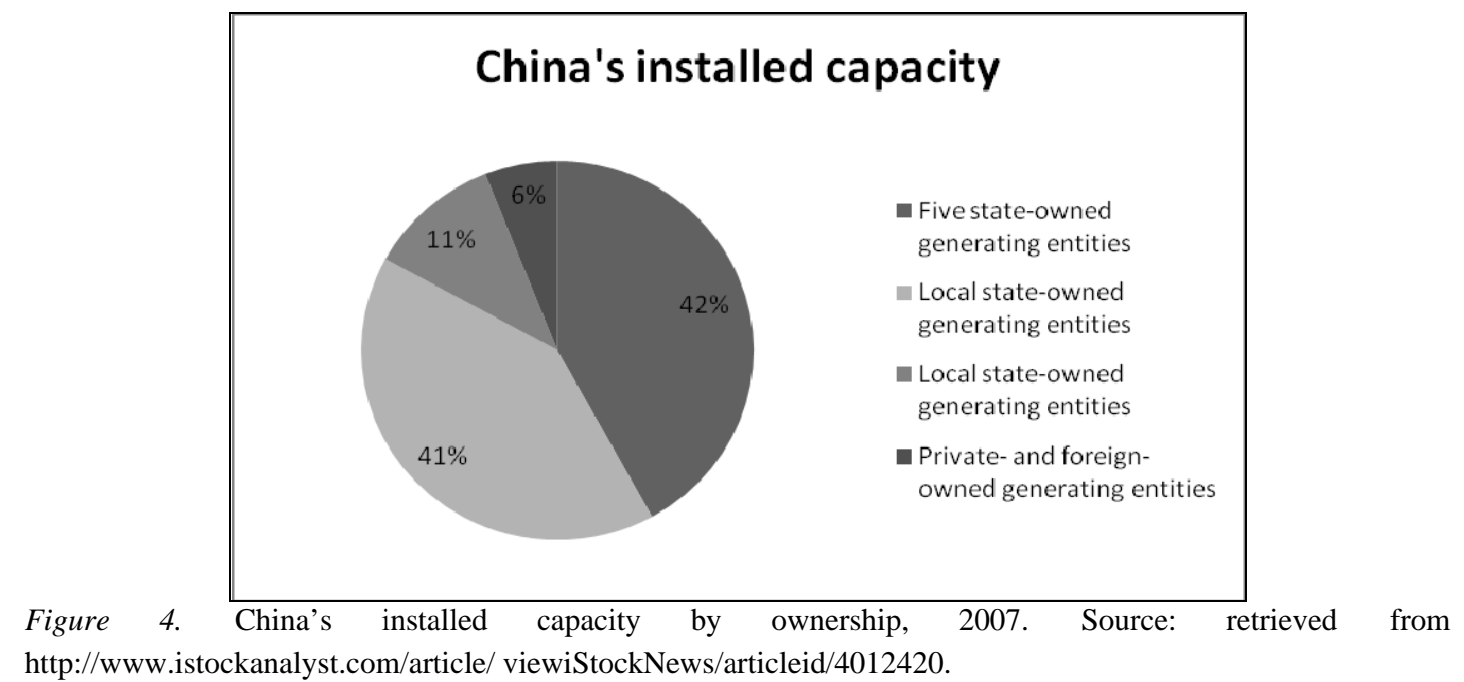

Since the foundation of the People's Republic of China in 1949, China's electricity industry has been a pillar in the construction of socialism. Like all other sectors of the economy, the electricity industry was state-owned and all the administrative decisions were taken by government officials. Investment in infrastructure was made by the central government and local governments and foreign firms were not allowed to invest (Yang, 2006). The industry was vertically structured and the integration of generation, transmission and distribution offered the usual economies of scale in the coordination of various functions minimizing thereby the costs of production and the costs of financing the infrastructure. Its management was a complicated structure of administrators all of them designated by the central government (Xu \& Chen, 2006). It was not till the early 1980s when China initiated its market-oriented reforms that the electricity industry entered an era of profound changes and reforms. But given the importance of the electricity industry as a key sector of the economy and political autonomy considerations, the reforms have been neither smooth nor easy to implement. They have been initiated and halted several times before they have put on track again. There are four phases in the reforms of the Chinese electricity industry:

(1) Reforms in investment in the generation segment of the electricity industry: In the 1985s, demand for electricity was increasing rapidly due to the accelerating growth rate in the manufacturing industries. This created a mismatch between demand and supply and the shortages of electricity supply were hindering the manufacturing sector to attain its full potential. The reforms undertaken by the central government allowed local governments and foreign companies to invest in the generation segment of the electricity industry but not in the other parts of

\footnotetext{
${ }^{9}$ After the Fukushima accident in Japan, the future of nuclear energy is uncertain in many countries. Recently, Germany has announced an end to its nuclear industry. For other nations, it remains to be seen whether the nuclear industry has a future.
} 
the industry. These reforms were aiming at increasing the rate of production of electricity but no reforms were made in the transmission and distribution segments. IPPs (Independent Power Producers) or CFGPs (Common financing generation plants) were totally independent from the MEP (Ministry of Electric Power) and they were linked to the transmission network by long term selling contracts. The success of reforms was quite satisfactory given that IPPs grew rapidly. By the end of 1990s the central government has already reduced its holdings to less than 50\% of generating capacity. Further, between 1996 and 2000, the share of central government in investment funds has declined to around $44.6 \%$. Private entities, local and foreign as well as local governments have made up the difference in the investment funds (Yang, 2006);

(2) Reforms in the management system and the establishment of the SPC: In the 1997s, it became apparent that further reforms were necessary and therefore a separation of business activities from the management activities was undertaken. The MEP could not manage its plants anymore and its entire property was transferred to the newly established public utility, SPC. The latter was independent from the central government entity, capable of administrating the daily operations of its generation, transmission and distribution networks. The MEP being without reason for existence was replaced by the State Economic and Trade Committee (SETC) which had the responsibilities to administrate and deal with other important decision-making functions. This was the final separation of business from administrative functions;

Table 3

Milestones in the Process of Restructuring of China's Electricity Industry

\begin{tabular}{|c|c|c|}
\hline $\begin{array}{l}\text { Restructuring and } \\
\text { regulation-Dates }\end{array}$ & Instrument & Goal \\
\hline 1985-1993 & $\begin{array}{l}\text { Local and provincial governments are allowed to invest in electricity } \\
\text { generation }\end{array}$ & $\begin{array}{l}\text { Promote electric power } \\
\text { development }\end{array}$ \\
\hline 1994-1999 & $\begin{array}{l}\text { Creation (in 1997) of SETC (the State Economic and Trade Commission). The } \\
\text { governance and regulatory functions of the Ministry of Electric Power are } \\
\text { transferred to SETC } \\
\text { Creation of the SPCC (the State Power Corporation of China). The SPCC } \\
\text { undertakes the business functions of the power sector }\end{array}$ & \\
\hline 2000-2010 & $\begin{array}{l}\text { 2002, Plan for Electric Power System Reform (State Council Notice No. 5). } \\
\text { Power generation assets transferred from the SPCC to five state-owned } \\
\text { holding companies. The transmission assets of the SPCC were allocated to the } \\
\text { State Grid Corporation of China (SGCC) and the China Southern Power Grid } \\
\text { Corporation (CSPGC) }\end{array}$ & $\begin{array}{l}\text { Introduce } \\
\text { principles by separating the } \\
\text { generation sector from the } \\
\text { transmission sector }\end{array}$ \\
\hline $\begin{array}{l}2002 \\
2003 \\
2005 \\
2008\end{array}$ & $\begin{array}{l}\text { Creation of the State Electricity Regulatory Commission } \\
\text { Creation of the Bureau of Energy } \\
\text { Creation of the Office of National Energy Leading Group (ONELG) } \\
\text { Replacement of NDRC's Bureau of Energy and of ONELG by the National } \\
\text { Energy Administration (NEA) and creation of the National Energy } \\
\text { Commission (NEC). }\end{array}$ & $\begin{array}{l}\text { Improve energy governance } \\
\text { and implement policies of } \\
\text { exploring RES, developing } \\
\text { energy strategies and managing } \\
\text { China's energy industries }\end{array}$ \\
\hline
\end{tabular}

Note. Source: Author's compilations.

(3) Reforms in the separation of generation and transmission segments: In the 2002s, further reforms were taken place and the government decided to unbundle the generation and transmission segments. Making the generation market competitive was one of the main objectives of this reform. Indeed, in 2002, the State Council separated the SPC into five generation companies, introducing de facto competition in this part of the market. SPC's transmission and distribution segments were assigned to two transmission companies. These reforms would not have been completed without the creation of a regulatory agency to regulate the restructured industry. 
Thus, in 2003, the central government created a new independent regulator, State Electricity Regulatory Commission (SERC), whose role was to regulate the newly restored industry, to enact rules and regulations for the smooth operation of the markets, monitor the functioning of the electricity markets and carry further the regulatory reforms. Indeed, SERC introduced wholesale competition and some regional wholesale markets were set up. However, the reforms did not last long. The regional wholesale market competition, while on trial, was suspended due to the increasing shortages of electricity all over China (see Table 3).

\section{Alternative Regulatory Frameworks for Renewable Energy in Europe and the USA-Fiscal Considerations}

\section{The FIT Programs and Their Cost}

The European Union (EU) and the United States (USA) have adopted different approaches to regulation of the electricity industry and they have used different regulatory frameworks to promote renewable energy sources (RES). No wonder the relative performance of these countries is entirely different. It is important to notice that both frameworks, the feed-in tariff (FIT) in Europe and the renewable portfolio standards (RPS) in the USA, have evolved over time and important modifications have been done on both to accelerate the pace of investments in electricity infrastructure with the goal to meet the Kyoto Protocol objectives.

RPS regulation or renewable portfolio standards obliges public utilities to source a specific percentage of their electricity from qualified renewable sources. There is no national regulation for RPS in the USA. Around 30 states have adopted RPSs as a means to encourage investment in electricity infrastructure using renewable. An economic consequence of this approach is the reduction in price volatility of fossil sources of energy. As with every other regulatory policy, the adoption of RPS programs has a cost which is paid by ratepayers and benefits which are shared by society. Apparently, the benefits outweigh the costs and such a policy is worth to be implemented. Given the objective to reduce carbon footprints, it is possible to use another approach to evaluate the efficacy of the RPS mechanism. i.e., to measure and compare the installed capacity in renewables in states having adopted the RPS and in states which have not. This is the approach used by the Lawrence Berkeley National Laboratory (LBNL). According to their recent estimates (2008), for the period 1998-2007, more than $50 \%$ of investment in non-hydroelectric renewable capacity has occurred in states having adopted the RPS programs. The year 2007 was even better in terms of renewable investments. Over $76 \%$ of investments in renewables occurred in states having RPSs programs. It is estimated that by the year 2025, the US will need roughly $61 \mathrm{GW}$ of new renewable capacity to satisfy the existing state RPS goals.

The costs of each approach are an important factor in deciding which one to implement ${ }^{10}$ in practice. Given that the costs of each program are reflected on prices paid by the final consumers the regulatory agencies may deem the increase in tariffs due to the introduction of these schemes as too excessive and may decide for the least expensive. This policy may be the preferred one based on costs even though the efficacy of this program in terms of $\mathrm{CO}_{2}$ reduction is not that good. By and large, increases in tariffs are higher under a FIT program than a RPS program. Under the former, prices paid for long term contracts to providers of renewable energy are far higher

\footnotetext{
${ }^{10}$ In some jurisdictions there may be constitutional constraints restricting the adoption of one scheme or the other. For instance, in the USA, FIT programs are considered illegal under the PURPA rule and considerable amendments are required to implement them (NREL, 2010). By contrast, if prices determined under the FIT program reflect “avoided costs" such programs may be legitimate but in many circumstances less efficient.
} 
than the "avoided costs" of investment in conventional energy sources. By contrast, given that prices for renewable energy sources, under a RPS program are market-based, the increase in tariffs to the final consumer may be smaller than under a FIT program. Indeed, the 2008 LBNL study found that prices have increased by a meager $1.2 \%$ in states with RPS programs. It is thus important for China to consider both options and the impact each one may have on the country's public finances and sustainability of its development path. Other studies (CPUC, 2009) show that more ambitious RPS programs with 33\% renewable in the portfolio, may result in hikes of electricity prices by $4 \%$ or even higher. Thus, the true costs of a RPS program vary depending on a number of factors, such as the content requirements of a portfolio in renewable, the market conditions in the jurisdiction, the regulatory policies, etc..

RPSs are not the only means to achieve the final result. Federal and state tax credits, long terms contracts for renewable projects and feed-in tariffs are other regulatory approaches used to give incentives to firms to increase investment in renewable sources of energy and reduce footprints carbon. These approaches can be used in conjunction with RPSs and some states in the US have done so. Nonetheless, there is a debate concerning the efficacy of these measures. European countries have used FIT programs since the beginning and there is more and more evidence that these programs, although more expensive than the RPSs, are more efficient to bring renewable sources of energy into the realm of reality. Nonetheless, the introduction of FIT programs and their impact on rates may be a factor that can dissuade China from introducing it. There is a trade-off. Either China uses FIT programs and reduces pollution faster than it was originally expected satisfying the international community and China accepts higher electricity tariffs or avoids sustainability problems by accepting low levels of electricity prices and higher pollution rates. There are however many variations of the FIT programs that allow a gradual reduction of pollution and a gradual rate rebalancing.

The original FIT programs use long term contracts to fix the price per $\mathrm{kWh}$ for a number of years specified in the contract. The use of FIT provides incentives to producers of renewable sources of energy to invest in the production of renewable technologies given the price and profit stability that bring these programs. Contrary to the RPSs which are market-based and therefore the price and the profits of the firms could vary substantially, the FIT programs guarantee the long term price of renewable energy and provide stability to the cash flows of investors.

Under the FIT contractual arrangement, the renewable energy generator is connected to the grid and is paid the price specified in the contract for feeding the network with renewable energy. It is expected that this scheme would create a robust market for renewable energy with eventually lower technology costs and higher potential for growth. The evidence from the EU indicates that the FIT programs work well and can be used to attain the Kyoto Protocol objectives rapidly. Germany, Spain and some Scandinavian countries have used the FIT program with a great success. Some states in the USA and lately Canada have adopted FIT programs. But as with the RPSs the design of a FIT program may vary significantly in terms of the duration of the contract, the eligibility of various technologies, the size of the renewable production (in terms of MWs), the way rates are calculated and other characteristics. It is argued that the most striking difference between FIT and RPS programs is in their long run sustainability. RPSs are more sustainable in the long run because rates are aligned with the market while rates under a FIT program are not connected to market conditions. In that sense, FIT programs are more expensive than RPSs programs.

Not all FIT programs provide equal incentives for the development of renewable energy sources. Depending on the design of the program, investors may get more or less incentives and this would have a net impact on the 
development of renewable resources. The graphic below shows the characteristics of alternative models used to encourage RES investment in electricity infrastructure.

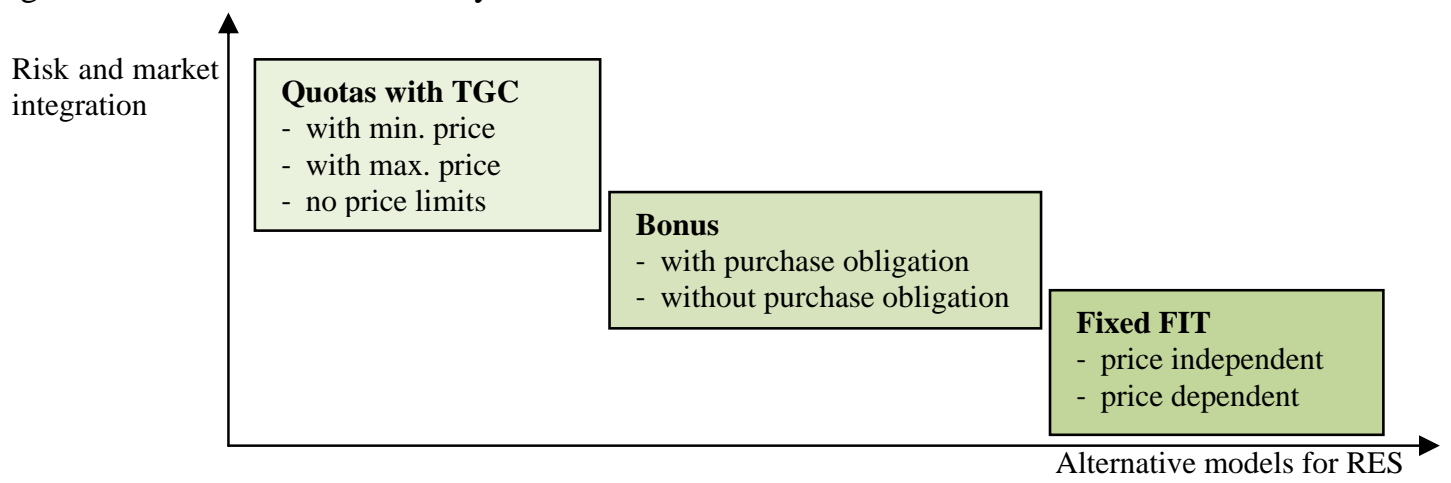

Figure 5. Risk and other market characteristics of alternative models for the promotion of RES.

Figure 5 indicates that some programs rely more on the market to bring faster the RES rather than on regulators but their efficiency is also different. FIT programs result in greener technologies faster. No matter whether they are more market or government inclined to bring the benefits of green technologies, there are some costs, direct and indirect, associated with all these programs. One of the most important indirect cost is the cost associated with the establishment of a sound institutional infrastructure. The latter is needed to support the rather complex policy mixes that are required to manage these programs and their processes. For instance, experienced regulatory bodies and other institutional infrastructure are an essential part of accomplishing the functions of verification, certification and monitoring the details of market operations. Other regulatory bodies such competition authorities have to get established to make sure that market competition works and penalties are imposed for non-compliance. China has to consider these problems before it implements one or several of these programs.

\section{China's Performance in RES Technologies and Its Public Finances}

Lately, China has made a great deal of progress in increasing its RES mix in its total energy production. Despite this progress, RES (excluding hydropower) account for less than $1 \%$ of its total installed capacity. Under China's Renewable Energy Law (2006), subsidies and tax breaks are used to support the development of RES while it imposes obligation requirements for the power grid to provide grid access to renewable power producers (Zhang, 2007). Several reasons explain this sharp increase in RES in China. Public's growing awareness of sustainability issues and China's willingness to promote RES for eventually complying with the Kyoto Protocol requirements is one of the reasons. But above all volatile resource prices and uncertain supplies, in conjunction with declining operating costs in wind and solar energy, made RES more attractive. Even large electricity companies have reaffirmed that RES offers them more possibilities to reduce their commercial risks over medium term. For instance, large companies are now willing to invest in RES projects with capacities in excess of 1 GigaWatt. As a result, investment in RES has increased by 60\% in 2007 (more than 150 billion USD) on a yearly basis. For instance, wind power in China was a mere 352 MW in 2000. By 2007, China's wind capacity has increased to $6 \mathrm{GW}$ (3.45 GW were added in 2007 alone) and by 2008 its wind capacity was already $12.2 \mathrm{GW}$, making China the fourth country worldwide in terms of wind energy capacity (NBSC, 2010). In a decade, China has succeeded to surpass its objectives in terms of wind capacity. According to official estimates (NDRC, 2008), wind will account for 3\% of electricity generation by 2020 . 
RES have grown very fast because of the wind power concession program launched in 2003 by NDRC. According to this program, international and domestic firms could bid to develop 100 MW wind farms with a fixed-price purchasing agreement (National Development and Reform Commission: Renewable Energy Law, 28 February, 2005). Although foreign firms had great difficulties to compete with domestic state-owned companies, nonetheless, more than 40 wind projects were approved by the end of 2007.

Despite the fact that China's Renewable Energy Law (2006) provides for preferential grid access for wind projects and offers tax breaks and subsidies to promote the development of RES, there are some enforcement problems which make the development of the grid slower than otherwise. According to the law, the wind price premium should be shared across the country but implementation is not consistent making grid operators less inclined to buy more expensive wind power to sell at capped retail prices and more reluctant to construct new transmission grids.

China has also become a world leader in solar energy technologies although its domestic solar market is less important. China is the third largest photovoltaic cell producer after Japan and Germany, accounting for $16.7 \%$ of global solar cell capacity (or $450 \mathrm{MW}$ in 2007) ${ }^{11}$. Without subsidies or other special funding, solar projects cannot compete with coal-fired plants. The declining importance of foreign markets (the prices in Spanish, German and American solar markets are declining) is pushing the Chinese government to initiate incentive programs, using subsidies and special funding for $\mathrm{R} \& \mathrm{D}$, to promote the development of solar energy at home.

Although the development of renewable sources of energy has been well embedded in China's policies, nonetheless, important subsidies still persist on fossil-fuel which dominates China's energy production (Wang, 2007). One way to measure the extent of subsidies is to use the price-gap measure. It is the difference between the actual price, the one that currently prevails in the market, and the price that would have resulted without the governments' subsidies ${ }^{12}$.

Energy subsidies have been estimated to be around 356.73 billion in 2007, equivalent to $1.43 \%$ of China's GDP (Lin \& Jiang, 2011). Given the sheer size of energy subsidies and their impact in favoring the use of fossil sources of energy with devastating effects on the environment, governments, particularly the central one, have to take it seriously and give the appropriate attention to remedy the current situation. In a most recent analysis of energy subsidies in China, Lin and Jiang (2011) stress the importance for the Chinese government to proceed in the reforms of energy subsidies as part of an effort to fulfill China's targets for the environment. It is also true that energy subsidies lead to inefficiencies in the consumption and production and their elimination brings prices closer to the ones resulting from markets creating thereby incentives for optimal investments and optimal or market-based levels of pollution.

In early 2009, China proceeded with the reforms in the oil pricing mechanism but subsidies in the electricity remained almost unscathed (Zhang, 2007; Wang, 2006). Social considerations were the main reasons for this piecemeal approach to reforming the pricing mechanisms for natural resources. Nonetheless, lately the Chinese government considered the possibility for reforming natural gas prices and tariffs for electricity for residential

${ }^{11}$ Chinese solar companies raise capital through listings in the US and Europe. Many of them consider the overseas markets as their markets for growth although the domestic market will start growing with the implementation of the government policies that would promote these technologies at home.

${ }_{12}$ Government programs that support various industries or people are not part of the price-gap model. Thus, the latter underestimates the true impact of government policies. 
customers. Volume differentiated tariffs are about to be introduced which will eventually lead to an elimination of cross subsidies. The supply of electricity at prices which are much lower than the cost of production, although satisfies social objectives, creates serious distortions which have to be addressed. One way to do it so is through the elimination of subsidies. As it was mentioned above, the distortions are twofold. One occurs at a static (allocative) level and results in static inefficiencies. The other occurs at a fiscal level and eliminating the cross-subsidies drastically, it may impact negatively on China’s sustainable path of development and increase risks.

The challenges to Chinese policymakers are multifold but the implementation of the reforms in the power industry in a way that subsidies are eliminated without disrupting China's path of development is not an easy task (Woo et al., 2006). One avenue is to proceed gradually so over a long period of time China's fiscal accounts are affected only marginally and the confidence financial markets have in China's capacity to deal with thorny problems of urbanization and aging population is not modified ${ }^{13}$. A drastic elimination would disrupt China's stable path of development through shocks on its fiscal accounts that would result in increases of risks premia and the cost of financing. Gradual adjustments would balance policy objectives against cost impacts, resulting in predictable fiscal deficits and a predictable market for renewable power.

\section{Conclusions and Policy Recommendations}

China's ever-increasing economic growth and the growing needs of its population exert a greater than ever pressure on its public finances. More and better public services mean larger public budgets and in many cases increasing public deficits. China, in order to be able to control the growth of its public deficit must consider certain strategies. Financing all public services using public funds would jeopardize the growth rates of the social market economy with lasting negative effects on China’s long term wealth generating capacity. Alternatively, a too rapid rebalancing and eventual increase in prices of public services may influence negatively consumers’ real purchasing power and hinder the growth of domestic demand. China should balance the results of both options and adopt a mixed strategy. Accept small budget deficits for a transitory period of time and restructure the prices of public services and bring them closer to market equilibrium.

The electricity sector, given its economic and political importance, has been protected from the vagaries of market economy for a long period of time. Electricity prices have been subsidized and this exerted a strenuous drain in public finances. China's domestic obligations (continue to growth and to offer better-quality of public services to its citizens) and its foreign ones make the reform of public services urgent. China is subject to foreign pressures to comply with the Kyoto Protocol and reduce gas emissions. To do so, the pricing structure of electricity sector must be changed to take into account the new and renewable energy sources which are more expensive but less polluting. To do so, China has to continue subsidizing, at least partially, the supply of renewable energy. FIT programs rather than RPSs programs may be used more intensively to increase the contribution of renewable energy in the total of energy production. These programs affect the public finances in different ways and China may examine the international experience and table a policy that minimizes the negative impact on its public finances. The European FIT environmental regulation is more efficient in bringing the anticipated results but it is also the most expensive one. This tradeoff must be taken into account when China

\footnotetext{
13 See Woo et al. (2006), Wolfram (1999), Tomas (2004, 2006) and Steiner (2000) for an interesting analysis of electricity reforms undertaken by various governments and their effects.
} 
elaborates its new regulatory framework for its electricity sector.

\section{References}

California Public Utilities Commission. (2009). 33\% renewable portfolio standard: Implementation analysis—Preliminary results. Retrieved from http://www.cpuc.ca.gov/NR/rdonlyres/ 1865C207-FEB5-43CF-99EB-A212B78467F6/0/33PercentRPSImplementationAnalysisInterimReport.pdf

China Banking Regulatory Commission. (2011). Retrieved from http://www.cbrc.gov.cn/english/home/jsp/index.jsp

China Electricity Council Statistics of Power Industry. (2010). Retrieved from http://www.linkschina.com/eN/index.php?option=com_content\&view=article\&id=507:china-electricity-council-statistics-ofpower-industry-2009\&catid=8: conventional-energy\&Itemid=11

Dow Jones International News. (2010). Retrieved from http://www.dowjones.com/info/business-news.asp?from=

Gipe, P. (2010). French lessons: Feed-in tariffs saved French ratepayers money they would have otherwise spent. Retrieved from http://www.grist.org/article/2010-09-13-feed-in-tariffs-saved-french-ratepayers-money-renewables-energy

IMF. (2010). Fiscal monitor, world economic and financial surveys, navigating the fiscal challenges ahead (p. 12). Report prepared by the Staff of the Fiscal Affairs Department, May 2010. Retrieved from http://www.imf.org/external/pubs/ft/fm/2010/fm1001.pdf

IStockAnalyst. Com. (2010). Update: China's power installed capacity to hit $950 \mathrm{mln} k w$ in 2010. Retrieved from http://www.istockanalyst.com/article/viewiStockNews/articleid/4012420

Lin, B., \& Jiang, Z. (2011). Estimates of energy subsidies in China and impact of energy subsidy reform. Energy Economics, 33(2), 273-283.

NARUC. (2010). Feed-in Tariffs (FIT): Frequently asked questions for state utility commissions. Retrieved from http://www.naruc.org/Publications/NARUC\%20Feed\%20in\%20Tariff\%20FAQ.pdf

National Bureau of Statistics of China. (2010). China statistical yearbook. Retrieved from http://www.stats.cn/tjsj/ndsj/2010/indexeh.htm

LBNL. (2008). Renewable portfolio standards in the United States: A status report with data through 2007. Primary authors, Wiser, R. and Barbose, G. Retrieved from http://www.lbl.gov/

NDRC. (2011). National development and reform commission: Renewable energy law. Retrieved from http://en.ndrc.gov.cn/

NREL (National Renewable Energy Laboratory). (2010). The relevance of generation interconnection procedures to feed-in tariffs in the United States. Prepared by Fink, S., K. Porter, and J. Rogers Exeter Associates, Inc. Columbia, Maryland. Retrieved from http://www.nrel.gov/analysis/publications.html

Qiu, X., \& Li, H. (2009). China's environmental super ministry reform: Background, challenges, and the future. Washington, D.C.: Environmental Law Institute ${ }^{\circledR}$.

Steiner, F. (2000). Regulation, industry structure and performance in the electricity supply industry. OECD Economics Department Working paper No. 238. Retrieved from http://ideas.repec.org/p/oec/ecoaaa/238-en.htmls

Thomas, S. (2004). Evaluating the British model of electricity deregulation. Annals of Public and Cooperative Economics, 75(3), 367-398.

Thomas, S. (2006). The British model in Britain: Failing slowly. Energy Policy, 34(5), 583-600.

Wang, B. (2007). An imbalanced development of coal and electricity industries in China. Energy Policy, 35(10), 4959-4968.

Wang, K. M. (2006). The deregulation of Taiwan electricity supply industry. Energy Policy, 34(16), 2509-2520.

Wiser, R., \& Barbose, G. (2008). Renewable portfolio standards in the United States: A status report with data through 2007. Retrieved from http://www.lbl.gov/

Wolfram, C. (1999). Measuring duopoly power in the British electricity spot market. The American Economic Review, 89(4), 805-826. Woo, C. K., King, M., Tishler, A., \& Chow, L. C. H. (2006). Costs of electricity deregulation. Energy Policy, 31(6-7), 747-768.

World Bank. (2010). Retrieved from http://siteresources.worldbank.org/chinaextn/resources/318949-1268688634523/quarterly_june_2010.pdf

Xu, S., \& Chen, W. (2006).The reform of electricity power sector in the PR of China. Energy Policy, 34(16), 2455-2465.

Yang, H. (2006). Overview of the Chinese electricity industry and its current issues. CWPE Working paper 0617. Retrieved from http://ideas.repec.org/p/cam/camdae/ 0617.htmls

Zhang, Y. F., Parker, D., \& Kirkpatrick, C. (2008). Electricity sector reform in developing countries: An econometric assessment to the effects of privatization, competition and regulation. Journal of Regulatory Economics, 33(2), 159-178.

Zhang, Z. (2007). China is moving away the pattern of “develop first and then treat the pollution'”. Energy Policy, 35(7), 3547-3549. 